\title{
Global warming and biodiversity model projections
}

\author{
Byung-Sun Ihm ${ }^{1, *}$, Jeom-Sook Lee ${ }^{2}$ and Jong-Wook Kim ${ }^{1}$ \\ ${ }^{1}$ Department of Biological Science, Mokpo National University, Muan 534-729, Korea \\ ${ }^{2}$ Department of Biology, Kunsan National University, Gunsan 573-701, Korea
}

\begin{abstract}
Many models intending to explain the latitudinal gradient of increasing species diversity from the poles to the equator are presented, which are a formalisation of the species-energy hypothesis. The model predictions are consistent with patterns of increasing species number with increasing mean air or water temperatures for plants and animals. An increase in species richness is also correlated with net primary production or the Normalised Difference Vegetation Index. This implies that increased availability of resources favours increased diversity capacity. The explanatory variables included in the biodiversity prediction models represent measures of water, energy, water-energy, habitat, history/evolution and biological responses. Water variables tend to be the best predictors when the geographic scope of the data is restricted to tropical and subtropical areas, whereas water-energy variables dominate when colder areas are included. In major models, about $20-35 \%$ of species in the various global regions (European, Africa, etc.) will disappear from each grid cell by 2050 and $>50 \%$ could be vulnerable or threatened by 2080 . This study provides good explanations for predictive models and future changes in biodiversity depending on various scenarios.
\end{abstract}

Key words: biodiversity, energy, global warming, model predictions, water, water-energy

\section{INTRODUCTION}

Continued greenhouse gas emissions at or above current rates will cause further warming and induce many changes in the global climate system in the 21st century that will likely be larger than those observed during the 20th century. Even if the concentrations of all greenhouse gases and aerosols is kept constant at the year 2000 levels, a further warming of about $0.1^{\circ} \mathrm{C}$ per decade is expected. Temperature projections increasingly depend on specific emissions scenarios (Kim 1998, Hughes 2000, Schneider 2001, Walther et al. 2002, IPCC 2007).

Most ecologists recognise two aspects of biodiversity that must be considered when trying to quantify biodiversity: species richness (the number of species in a community) and relative abundance or equitability (the evenness with which individuals are spread out among the species in a community) (Whittaker et al. 2001, Barnard and Thuiller 2008). Biodiversity is usually defined in terms of molecules, genes, species and ecosystems and corresponds to four fundamental and hierarchically related levels of biological organisation (Campbell 2003). Because of the major influence of climate on range shifts, extinctions, distribution and vegetation types from continental to regional scale, it is expected that climate change will alter biodiversity considerably (Ricklefs 1987, Malanson 1993, Hughes 2000, Hansen and Dale 2001, Hansen et al. 2001, Bakkenes et al. 2002, Walther et al. 2002, Thuiller et al. 2005, Thuiller 2007, Shin et al. 2009, Wang et al. 2009, Rocchini et al. 2010, Kim 2012). The level of anthropogenic stress on biodiversity is far greater than that imposed by natural global climatic changes occurring in the re-

\section{Open Access http://dx.doi.org/10.5141/JEFB.2012.022}

This is an Open Access article distributed under the terms of the Creative Commons Attribution Non-Commercial License (http://creativecommons org/licenses/by-nc/3.0/) which permits unrestricted non-commercial use distribution, and reproduction in any medium, provided the original work is properly cited.
Received 03 May 2012, Accepted 13 June 2012

*Corresponding Author

E-mail: ihmbs@mokpo.ac.kr

Tel: +82-61-450-2343 


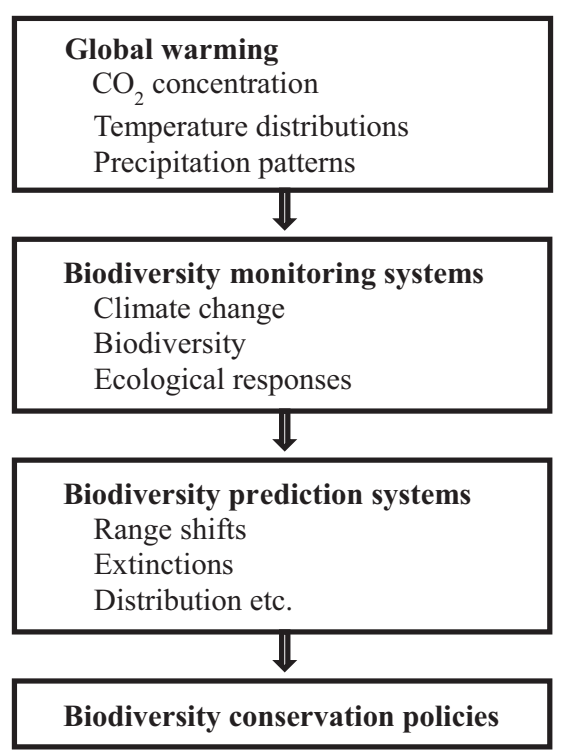

Fig. 1. Species diversity prediction and conservation with global warming.

cent evolutionary past, including temperature increases, shifts in climate zones, melting of snow and ice, sea level increases, droughts, floods, and other extreme weather events. Natural systems are vulnerable to such changes because of their limited adaptive capacity (Pimm and Gittleman 1992, Vitousek 1994, Pimm et al. 1995, Chapin et al. 2000, Warren et al. 2001, Ihm et al. 2007, Fonty et al. 2009).

The objectives of this study are (a) to identify the impacts of global warming on biodiversity and (b) to provide explanations for predictive models and future changes in biodiversity (Fig. 1). These predictions need to be temporally and spatially explicit to allow ecologists and managers of protected areas to plan for the greatest number of species possible. The predictions based on credible modelling can guide the establishment of monitoring programmes to serve as early warning signs of the climate change trajectory. Furthermore, explicit predictions will allow safe limits of climate change to be defined and will aid in the development of policy guidelines on carbon emissions.

\section{BIODIVERSITY PREDICTION MODELS}

Allen et al. (2002) presented the species-energy hypothesis, which was intended to explain the latitudinal gradient of increasing species diversity from the poles to the equator. This model's predictions are consistent with patterns of increasing numbers of plant and animal species with increasing mean air or water temperatures. Substantial evidence indicates that a broadly positive monotonic relationship between species richness and energy availability is common at geographical scales across temperate to polar areas (Dobzhansky 1950, Pianka 1966, Turner et al. 1988, Currie 1991, O'Brien 1998, Rutherford et al. 1999, Gaston 2000, Lennon et al. 2000, Francis and Currie 2003, Hawkins et al. 2003, Root et al. 2003, Hawkins and Pausas 2004, Evans et al. 2005, De Boeck et al. 2007, Ihm et al. 2007, Peñuelas et al. 2007, Whittaker et al. 2007). The best correlates for terrestrial and marine animals are measures of energy, such as temperature, whereas the best correlates for plants tend to be measures of both water and energy, such as precipitation, temperature and net primary production (NPP) (Stevens 1989, Willig and Lyons 1998, Gaston 2000, Allen et al. 2002, Field et al. 2005, Mutke and Barthlott 2005, Barthlott et al. 2007, Kreft and Jetz 2007). The species richness of trees in East Asia, temperate Europe, and eastern North America increases with primary productivity. In contrast, factors such as mean annual precipitation, actual evapotranspiration or the number of days per year with rainfall have a much a closer relationship with species richness in the thermally more suitable tropics (Hawkins et al. 2003, Currie et al. 2004, Field et al. 2005, Mutke and Barthlott 2005, Barthlott et al. 2007, Kreft and Jetz 2007). The still developing "metabolic theory of ecology" (MTE) claims to derive ecological relationships from the structure of resource distribution networks, which is assumed to determine the scaling of metabolism with body mass from the effect of temperature on the rate of biological processes and from a range of macroecological patterns including diversity gradients (Allen et al. 2002, Brown et al. 2004, van der Meer 2006, Allen and Gillooly 2007). The observed diversity gradients are consistent with the MTE predictions across a wide range of taxonomic groups in almost all regions of the world (Hawkins et al. 2007). It is obvious that water is essential for any terrestrial system diversity at all, and it is possible that in systems where water is not limiting, enzyme kinetics could explain the observed gradients. Smaller scale gradients, such as those along mountain slopes, might also conform better to MTE predictions. It is anticipated that future climatic warming will change the distribution limits of many vascular plant species (Sætersdal et al. 1998). Stevens (1989) proposed Rapoport's rule as a possible explanation for the higher species richness of animals and plants in the tropics. The rule postulates that tropical species have smaller ranges on average, than temperate taxa because of the tolerance of temperate species to a broader range of environmen- 
tal conditions. Rapoport's rule has been shown to apply to some groups in some continents, but the exceptions to the rule are numerous; therefore, its generalisability has been seriously questioned. Other perspectives for studying latitudinal gradients of species richness came from the mid-domain models developed during the 1990s (Colwell and Hurtt 1994, Willig and Lyons 1998, Colwell and Lees 2000, Arita 2005). In two-dimensional models, a similar peak in species richness appears in the centre of a bounded domain defined by latitude and longitude. The term "mid-domain models" comes from these predicted patterns of the highest richness at the middle of the gradient.

An increase in animal or plant species richness correlates with NPP or the Normalised Difference Vegetation Index (NDVI) (Alward et al. 1999, Evans et al. 2005, Leyequien et al. 2007, Woodward and Kelly 2008, Kim and You 2010) through a number of potential mechanisms, such as complementarity of resource use and positive interspecific interactions. This implies that an increase in the availability of resources favours an increase in diversity capacity (Morin 2000). At the global scale of investigation, NPP is a measure of resource availability for plants and is determined by geographic variations in climatic and edaphic characteristics and can be readily simulated. Woodward and Kelly (2008) investigated the premise that plant diversity is determined by NPP, while becoming aware that different geographical locations may have very different geological histories and species pools, which could lead to different NPP-diversity relationships. This model has two fundamental flaws concerning the species-energy hypothesis (Huston 2003, Brown et al. 2004). 1) Mean temperature does not correspond to the energy actually available to organisms, which is the energy stored in carbon compounds produced by photosynthesis. Although it is true that the tropics tend to be warmer than the temperate zone, higher temperatures do not necessarily result in higher plant productivity. 2) High species diversity occurs in cold or low-productivity environments.

The well-known species-area relationship $\left(S=\mathrm{cA}^{\mathrm{z}}\right) \mathrm{ex}-$ plains species richness on a local to regional scale (Whittaker et al. 2001, Thomas et al. 2004, Woodward and Kelly 2008, Ulrich and Fiera 2009, Henry et al. 2010). Area per se is a relatively weak predictor of species richness and explains only $6.6 \%$ of the global variation in plant species richness (Kreft and Jetz 2007). However, the explanatory power of area dramatically increases when spatial autocorrelation is explicitly modelled (57.4\% deviance). This indicates strong neighbourhood effects.
Habitat factors (e.g., topography, soil, land use, disturbance, and climate), historical/evolutionary factors, and biotic factors (e.g., invasion, competition, predation, niche difference, and natural enemies) influence habitat and species differentiation of communities and might explain the higher biodiversity of geodiverse regions (Grime 1974, Connell 1978, Shmida and Wilson 1985, Rohde 1992, Palmer 1994, Pimm et al. 1995, Chapin et al. 2000, Sala et al. 2000, Whittaker et al. 2001, Hawkins et al. 2003, Currie et al. 2004, Hubbell 2005, 2006, Barthlott et al. 2007).

\section{FUTURE CHANGES IN BIODIVERSITY}

Table 1 includes response variables, model types, extents, explanatory variables and climate data or global climate models (GCMs) simulated, but most of the explanatory variables represent measures of water (precipitation, moisture availability index and water deficit), energy (temperature, NPP, and NDVI), ecophysiological responses, topographic complexity and population dynamics (Jetz and Rahbek 2002, Midgley et al. 2002, Hawkins et al. 2003, Venevsky and Veneskaia 2003, Lemoine et al. 2007). Furthermore, water variables tend to be the best predictors when the geographic scope of the data is restricted to tropical and subtropical areas, whereas water-energy variables dominate when colder areas are included. In cold regions, where energy inputs are lower and thus more likely to be limiting, energy interacts with water to explain richness gradients.

Although evidence for extinctions caused primarily by climate change is relatively limited, many projections suggest serious future concerns for many species (Thomas et al. 2004, Thuiller et al., 2005, Huntley et al. 2008, Olofsson et al. 2008, Sinervo et al. 2010). One estimate indicates that $~ 86 \%$ of the plant and animal species assessed are likely to be at increasingly high risk of extinction caused by climate change in the 21st century. At the local scale, Guisan and Theurillat (2000) and Dirnböck et al. (2003) showed that mountainous plants at high elevations are particularly susceptible to extinction. Up to $25 \%$ of the plant species now present in southern Europe may disappear by 2100 (Bakkenes et al. 2006).

Temperature is a better predictor of avian species richness than is NDVI in models restricted to a single measure of energy availability, but it is important to note that temperature and NDVI are correlated (Table 1) (Evans et al. 2005). NDVI measures are retained in most of the best-fitting spatial regression models. The relationship between avian communities and climatic conditions is 
dependent on the energy metric used, with species richness being more closely correlated with temperature than with the NDVI, which is a strong correlate of NPP (Evans et al. 2005, Leyequien et al. 2007).

Lemoine et al. (2007) developed spatial regression models and quantified the relationship between the pro- portion of migratory and resident bird species and climatic conditions (Table 1). They used the mean temperature of the coldest month (TCM), the mean spring temperature (TSPR, average of April, May and June) and spring precipitation (PSPR, average of April, May and June) as measures of climatic conditions in winter and during the

Table 1. Biodiversity prediction models based on several methods

\begin{tabular}{|c|c|c|c|c|c|}
\hline Response variables & Model type & Extent & $\begin{array}{l}\text { Explanatory } \\
\text { variables }\end{array}$ & $\begin{array}{l}\text { Climate data or GCMs } \\
\text { simulated }\end{array}$ & Reference \\
\hline Avian species richness & Spatial regression & Britain & T, NDVI & $\begin{array}{l}\text { Meteorological station, } \\
\text { NOAA/NASA Path- } \\
\text { finder AVHRR Land } \\
\text { Data Set }\end{array}$ & $\begin{array}{l}\text { Evans et al. } \\
2005\end{array}$ \\
\hline Avian species richness & $\begin{array}{l}\text { Multiple regression and } \\
\text { Mantel test }\end{array}$ & Europe & $\begin{array}{l}\text { TCM, TSPR, } \\
\text { PSPR }\end{array}$ & HadCM3 & $\begin{array}{l}\text { Lemoine et al. } \\
2007\end{array}$ \\
\hline Avian species richness & Species-area approach & Europe & A, D & $\begin{array}{l}\text { GFDL, HadCM3, } \\
\text { ECHAM4 }\end{array}$ & $\begin{array}{l}\text { Huntley et al. } \\
2008\end{array}$ \\
\hline Lizard diversity & Multiple regression & Global & $\mathrm{T}_{\mathrm{b}}, \mathrm{H}_{\mathrm{r}}, \mathrm{TB}$ & WorldClim database & $\begin{array}{l}\text { Sinervo et al. } \\
2010\end{array}$ \\
\hline $\begin{array}{l}\text { Tuna and billfish } \\
\text { richness }\end{array}$ & Spatial regression & Global ocean & $\begin{array}{l}\text { SST, SSTG, } \\
\text { DO }\end{array}$ & Remotely sensed data & $\begin{array}{l}\text { Worm et al. } \\
2005\end{array}$ \\
\hline $\begin{array}{l}\text { Vertebrate and woody } \\
\text { plant species richness }\end{array}$ & Multiple regression & $\begin{array}{r}\text { Conterminous } \\
\text { United States }\end{array}$ & $\begin{array}{l}\text { Jan temp. } \\
\text { Jul temp. } \\
\text { Jan precip. } \\
\text { Jul precip. }\end{array}$ & $\begin{array}{l}\text { CGCM1, OSU, GFDL, } \\
\text { GISS, UKMO }\end{array}$ & $\begin{array}{c}\text { Currie } \\
2001\end{array}$ \\
\hline $\begin{array}{l}\text { Animal and plant } \\
\text { extinction }\end{array}$ & Species-area approach & $\begin{array}{l}\text { Amazonia } \\
\text { Europe } \\
\text { Cerrado } \\
\text { South Africa }\end{array}$ & $A, D$ & $\begin{array}{l}\text { Three scenarios ac- } \\
\text { cording to tempera- } \\
\text { tures and } \mathrm{CO}_{2} \text { levels }\end{array}$ & $\begin{array}{l}\text { Thomas et al. } \\
2004\end{array}$ \\
\hline Plant diversity & $\begin{array}{l}\text { Multiple logistic } \\
\text { regression }\end{array}$ & Europe & $\begin{array}{l}\text { T, M, P, PET, } \\
\text { AET, LGS, } \\
\text { SGS, AR }\end{array}$ & $\begin{array}{l}\text { IMAGE } 2.1 \text { model } \\
\text { (Alcamo 1994) \& } \\
\text { IIASA climate data- } \\
\text { base (Leemans and } \\
\text { Cramer 1991) }\end{array}$ & $\begin{array}{l}\text { Bakkenes et al. } \\
2002\end{array}$ \\
\hline Plant species richness & $\begin{array}{l}\text { Generalised linear mod- } \\
\text { els, generalised additive } \\
\text { models, and artificial } \\
\text { neural networks }\end{array}$ & Europe & GD, M & $\begin{array}{l}\text { Climatic Research Unit } \\
\text { in UK }\end{array}$ & $\begin{array}{l}\text { Thuiller et al. } \\
2005\end{array}$ \\
\hline Plant species richness & Multiple regression & Global & T, P & $\begin{array}{l}\text { World Weather Infor- } \\
\text { mation Service }\end{array}$ & $\begin{array}{l}\text { Ihm et al. } \\
2007\end{array}$ \\
\hline Plant species richness & $\begin{array}{l}\text { Nonspatial and spatial } \\
\text { regression }\end{array}$ & Global & $\mathrm{T}, \mathrm{A}, \mathrm{P}, \mathrm{W}$ & $\begin{array}{l}\text { Digitally available } \\
\text { global data sets }\end{array}$ & $\begin{array}{l}\text { Kreft and Jetz } \\
2007\end{array}$ \\
\hline Woody plant richness & $\begin{array}{l}\text { Explanatory } \\
\text { regression models }\end{array}$ & Africa & $\begin{array}{l}\text { P, PET, AET, } \\
\text { WD }\end{array}$ & $\begin{array}{l}\text { Climate data from } 980 \\
\text { stations }\end{array}$ & $\begin{array}{l}\text { Field et al. } \\
2005\end{array}$ \\
\hline
\end{tabular}

T, temperature; NDVI, normalised difference vegetation index; TCM, mean temperature of the coldest month; TSPR, mean spring temperature; PSPR, spring precipitation; HadCM3, Hadley Centre Coupled Model (Gordon et al. 2000); A, area; D, dispersal; GFDL, Geophysical Fluid Dynamics Laboratory Coupled Model (The GFDL Global Atmospheric Model Development Team 2004); ECHAM4, the Max Planck Institute for Meteorology's ECHAM GCM (Roeckner et al. 1996); $T_{b}$, body temperature; $H_{r}$, hour in activity during reproduction; TB, timing of breeding; SST, remotely sensed sea surface temperature; SSTG, SST gradients; DO, dissolved oxygen; CGCM, the Canadian Climate Centre high-resolution GCM model (Boer et al. 1992); OSU, the Oregon State University model (Schlesinger and Zhao 1989); GISS, the Goddard Institute for Space Studies model (Hansen et al. 1999); UKMO, the UK Meteorological Office low-resolution model (Wilson and Mitchell 1987); M, moisture availability index; P, precipitation; PET, potential evapotranspiration; AET, actual potential evaporation; LGS, length of growing season; SGS, start of growing season; AR, annual runoff; GD, growing-degree days; W, wet days, WD, water deficit. 
breeding period. The spatial relationship between avian communities and climatic conditions was derived from spatial regression models in Europe (Lemoine and Böhning-Gaese 2003). The proportion of long- and short-distance migratory species was well described by TCM, TSPR and PSPR $\left(r^{2}=68.7 \%\right.$ for long-distance migratory species, $r^{2}=59.8 \%$ for short-distance migratory species), and the relationship with the climatic variables for a proportion of resident species was weak $\left(r^{2}=26.3 \%\right)$. They found that the proportion of long-distance migrants increased and the proportion of short-distance migrants decreased with increasing spring temperature in a spatial analysis across Europe.

For six climate scenarios between 2070 and 2099, changes were estimated for 431 European breeding avian species using models relating species' distributions in Europe to climate (Table 1) (Huntley et al. 2008). It was estimated that the average number of species breeding per $50-\mathrm{km}$ grid square would decrease by $6.8-23.2 \%$. The simulated reduction in mean range extent resulted in a reduction in the simulated mean number of breeding species per grid cell and hence a general decrease in local avian species richness across Europe. Of the scenarios examined, the smallest effect (a 6.8\% average reduction in the number of species breeding in a $50-\mathrm{km}$ grid square) was observed for the GFDL B2 scenario when assuming perfect dispersal, whereas the largest effect (a $56.4 \%$ average reduction in the number of species breeding in a $50-\mathrm{km}$ grid square) was observed for the ECHAM4 A2 scenario when assuming dispersal failure (Ibáñez et al. 2006).

The lizard diversity model, based on body temperature $\left(\mathrm{T}_{\mathrm{b}}\right)$, hours of activity during reproduction $\left(\mathrm{h}_{\mathrm{r}}\right)$ and timing of breeding, assesses salient adaptations that affect thermal extinctions (Sinervo et al. 2010). Geo-referenced $T_{b}$ samples indicate that local extinctions in 2009 averaged $4 \%$ worldwide. Global averages will increase four-fold to $16 \%$ by 2050 and nearly eight-fold to $30 \%$ by 2080 , whereas equatorial extinctions will reach $23 \%$ by 2050 and $40 \%$ by 2080 .

The richness of tuna and billfish species showed a consistent global pattern, indicating peaks of diversity at intermediate latitudes ( 15 to $30^{\circ} \mathrm{N}$ or S) and lower diversity toward the poles and at the equator (Table 1) (Worm et al. 2005). In an effort to determine which oceanographic variables might explain global patterns of predator diversity, they explored the effects of remotely sensed sea surface temperatures (SST) (mean and spatial gradients), dissolved oxygen levels, eddy kinetic energy, chlorophyll $a$ (mean and spatial gradients) and depth (mean and spatial gradients) on diversity using spatial regression models
(Table 1). Stepwise elimination of non-significant variablesindicated that mean temperature, SST gradients and oxygen were the main factors. A third-order polynomial model of SST produced the best fit for global predator diversity. Diversity over the past 50 years declined between $10 \%$ and $50 \%$ in all oceans, a trend that coincided with increased fishing pressure superimposed on strong El NiñoSouthern Oscillation-driven variability across the Pacific.

For trees and birds, the positive coefficient on the linear term for July temperature indicates that richness initially increased with increasing temperature, but that the relationship decelerated (Table 1) (Currie 2001). Eventually, richness reached a maximum and then began to decrease. Multiple regression models including temperature and precipitation account statistically for $83-94 \%$ of the contemporary North American variation in species richness in trees and birds. Climate change should lead to variable changes in species richness across the contiguous United States. The results suggest that marked increases in the richness of most taxa are likely to occur in cool regions, whereas decreases in homoeotherm richness are likely to occur in parts of the South.

Thomas et al. (2004) explored methods for estimating animal and plant extinction based on the species-area relationship $\left(\mathrm{S}=\mathrm{CA}^{\mathrm{z}}\right.$, where $\mathrm{S}$ is the number of species, $\mathrm{A}$ is the area, and $\mathrm{c}$ and $\mathrm{z}$ are constants). This relationship adequately predicts the numbers of animal and plant species that become extinct or threatened when the area available to them is reduced by climate change (Ibáñez et al. 2006, Huntley et al. 2008). Minimum expected climatechange scenarios for 2050 produce fewer projected "committed extinctions" (18\%) than do mid-range projections $(24 \%)$ and about half of those predicted under maximum expected climate change (35\%).

Bakkenes et al. (2002) studied a geographically explicit quantification of the possible effects of forecasted climate change on the diversity of the European flora (Table 1). A species-based probabilistic model, Euromove, has been developed. Euromove calculations resulted in climate envelopes for nearly 1,400 plant species. EuRomove integrates calculated regression equations to analyse the effects of climate change on the European flora. According to Euromove calculations, the results show major changes for_biodiversity by 2050 . On average, $32 \%$ of the 1,990 species would disappear from each grid cell.

The relationship between the modelled percentage of species loss and the anomalies for the two most significantly correlated bioclimatic variables-growing-degree days (accumulated warmth) and the moisture availability index-was used to identify the potential causes of varia- 
tion in predicted plant diversity changes across regions within and across scenarios (Thuiller et al. 2005) (Table 1). Multiple linear regression with the use of these two predictors explained $60 \%$ of the variance across scenarios. Applying the International Union for Conservation of Nature and Natural Resources (IUCN) Red List criteria to their projections showed that many European plant species could become severely threatened. More than half of the species they studied could be vulnerable or threatened by 2080. Expected species loss per pixel (a $50 \times 50$ $\mathrm{km}$ grid) proved to be highly variable across scenarios (27$42 \%$, averaged over Europe) and across regions (2.5-86\%, averaged over scenarios).

Ihm et al. (2007) analysed 40 climatological and two geographic variables for 90 countries in the Northern Hemisphere to investigate the predictors that explained the variances in species richness (Table 1). When multiple regression models were used to evaluate this variance, the model $r^{2}$ was 0.431 . This variance could be explained by the 11 variables related to temperature (T) and precipitation (P): February $\mathrm{T}_{\text {MIN }}$, March $\mathrm{T}_{\text {MIN }}$, May $\mathrm{T}_{\text {MAX }}$, October $\mathrm{T}_{\text {MAX }}$, November $\mathrm{T}_{\text {MAX }}$, December $\mathrm{T}_{\text {MAX }}$, March $\mathrm{P}$, July P, October P, November P, and December P. Latitude and country area (two geographic variables) had negative and positive influences on species richness, respectively. Lower-latitude sites showed greater richness than did higher-latitude sites. This latitudinal gradient in species richness is a consequence of spatial variation in both the immigration and extinction of species (Pianka 1966, Gaston 2000, Ihm et al. 2007). For very large land masses, the effects of speciation and regional or global extinction will predominate, and immigration and emigration will be less important.

Kreft and Jetz (2007) used both non-spatial and spatial modelling techniques to test the predictive potential of variables. Predictive models of plant species diversity were developed globally by country to show that future plant diversity capacity has a strong dependence on changing climate (Table 1). A significant positive effect of average annual temperature on vascular plant species richness ( $8.5 \%$ deviance in the general linear model; GLM) was observed. Actual evapotranspiration emerged as the strongest single climatic predictor ( $28.6 \%$ deviance). Water-energy models that include interaction terms tend to have stronger explanatory power than do those with only main effects. They constructed a GLM and the spatial linear model (SLM) multi-predictor model (Kraft and Jetz 2007). The six explanatory variables included area $\left(\mathrm{km}^{2}\right)$, potential evapotranspiration $(\mathrm{mm} / \mathrm{y})$, annual number of days with rainfall, number of 300-m elevation belts per geographic unit (range of elevation divided by 300) + the number of different vegetation types and three-dimensional structural complexity. This model explained $65.9 \%$ of the observed deviance in a GLM framework and $70.2 \%$ in a spatial linear model.

A model that is grounded on biological relativity to water-energy dynamics is the interim general model (IGM1 and IGM2) of the climatic potential for woody plant richness (Field et al. 2005). IGM1 describes horizontal climate-richness relationships based on annual rainfall $\left(\mathrm{R}_{\mathrm{an}}\right)$ and minimum monthly potential evapotranspiration $\left(\mathrm{PET}_{\min }\right)$; IGM2 additionally incorporates vertical changes in climate due to topographic relief. For the southern subcontinent of Africa (from $15^{\circ} \mathrm{S}-35^{\circ} \mathrm{S}$ latitude), the re-described regression models apply to the full range of global variation in all independent climate variables in the woody plants of Kenya. They concluded that the IGMs are globally applicable and provide a fundamental baseline for systematically estimating differences in woody plant richness (Field et al. 2005). Predictions of actual woody plant richness using IGM2 are mostly reasonable or close fits, with a slight increase in precision found among IGM2 predictions.

The most obvious use of predictive variables and models is to predict species richness when actual values are unknown (Table 1) (Bakkenes et al. 2002, Field et al. 2005). First, the predictive models provide a line of evidence for evaluating whether or not this is the case elsewhere in the world. Second, given that they invoke dynamic climatological variables, the predictive models can be linked directly to GCMs and used to examine how future changes in climate could alter present-day richness patterns. Predictions at the macro scale can be incorporated as potential richness in analyses of how other variables relate to richness (O'Brien et al. 2000, Whittaker et al. 2001). The models of Kreft and Jetz (2007) successfully explain the species richness gradient, or the predicted global map confirms many regional trends and hotspots anticipated previously. They have shown that relatively few variables, namely a combination of high annual energy input with constant water supply and extraordinarily high spatiotopographic complexity, can accurately predict the future change in plant richness.

Many European endemic species will have little or no overlap between their present and potential future ranges (Huntley et al. 2008); such species face an enhanced extinction risk as a consequence of climatic change. Although many human activities exert pressures on wildlife, the magnitude of the potential effects estimated for European breeding birds emphasises the importance of 
climate change. The response of woody plant species to climate change in climate models can dramatically influence forecasts of potential future changes in avian diversity (Shanahan et al. 2001). Models assuming a strong time lag in the response of woody plants to climate change forecast significantly stronger decreases in avian species richness under climate change than do models in which woody plant species richness are allowed to show an instantaneous response to climate change. Future changes in the distribution of woody plants might be important for birds from a trophic perspective. Particularly in the tropics, many woody plants provide important food resources for avian consumers, including fleshy-fruited trees and shrubs for frugivorous species (Shanahan et al. 2001).

\section{SUGGESTIONS}

We suggest four strategies for researchers to monitor species distribution and reduce biodiversity loss by the negative impacts of climate change (Sala et al. 2000, Currie 2001, Hansen and Dale 2001, Bakkenes et al. 2002, Midgley et al. 2003, Thomas et al. 2004, Worm et al. 2005, Botkin et al. 2007, Kreft and Jetz 2007, Huntley et al. 2008). First, minimising greenhouse gas emissions and sequestering carbon to realise minimum expected climate warming could substantially reduce the loss in biodiversity. Second, conservation efforts need to be expanded in scale and scope to mitigate biodiversity loss, particularly on nature reserves. Third, mechanistic or empirical models could offer an alternative approach to forecasting the effects of climate change. We suggest that there is now a wide scope for an integrated framework to forecast the impacts of global change on biodiversity. Such a framework could integrate models for species persistence and consider multiple causes of biodiversity change. Fourth, biodiversity in many ecosystems is sensitive to global changes in the environment and land use, and realistic projections of biodiversity change will require an integrated effort by climatologists, ecologists, social scientists, and policy makers to improve future change scenarios. Refinement of these models will require quantitative regional analyses, and a study of the interactions between the factors to which local biodiversity is most sensitive.

\section{LITERATURE CITED}

Alcamo J. 1994. Image 2.0: Integrated Modelling of Global Climate Change. Kluwer Academic Publishers, Dor- drecht.

Allen AP, Brown JH, Gillooly JF. 2002. Global biodiversity, biochemical kinetics, and the energetic-equivalence rule. Science 297: 1545-1548.

Allen AP, Gillooly JF. 2007. The mechanistic basis of the metabolic theory of ecology. Oikos 116: 1073-1077

Alward RD, Detling JK, Milchunas DG. 1999. Grassland vegetation changes and nocturnal global warming. Science 283: 229-231

Arita HT. 2005. Range size in mid-domain models of species diversity. J Theor Biol 232: 119-126.

Bakkenes M, Alkemade JRM, Ihle F, Leemans R. Latour JB. 2002. Assessing effects of forecasted climate change on the diversity and distribution of European higher plants for 2050. Glob Chang Biol 8: 390-407.

Bakkenes M, Eickhout B. Alkemade R. 2006. Impacts of different climate stabilisation scenarios on plant species in Europe. Glob Environ Chang 16: 19-28.

Barnard P, Thuiller W. 2008. Introduction. global change and biodiversity: future challenges. Biol Lett 4: 553-555.

Barthlott W, Hostert A, Kier G, Küper W, Kreft H, Mutke J, Rafiqpoor MD, Sommer JH. 2007. Geographic patterns of vascular plant diversity at continental to global scales. Erdkunde 61: 305-315.

Boer GJ, McFarlane NA, Lazare M. 1992. Greenhouse gasinduced climate change simulated with the CCC second-generation general circulation model. J Climate 5: 1045-1077.

Botkin DB, Saxe H, Araújo MB, Betts R, Bradshaw RHW, Cedhagen T, Chesson P, Dawson TP, Etterson JR, Faith DP, Ferrier S, Guisan A, Hansen AS, Hilbert DW, Loehle C, Margules C, New M, Sobel MJ, Stockwell DRB. 2007. Forecasting the effects of global warming on biodiversity. BioScience 57: 227-236.

Brown JH, Gillooly JF, Allen AP, Savage VM, West GB. 2004. Toward a metabolic theory of ecology. Ecology 85: 17711789.

Campbell AK. 2003. Save those molecules: molecular biodiversity and life. J Appl Ecol 40: 193-203.

Chapin FS III, Zavaleta ES, Eviner VT, Naylor RL, Vitousek PM, Reynolds HL, Hooper DU, Lavorel S, Sala OE, Hobbie SE, Mack MC, Diaz S. 2000. Consequences of changing biodiversity. Nature 405: 234-242.

Colwell RK, Hurtt GC. 1994. Nonbiological gradients in species richness and a spurious Rapoport effect. Am Nat 144: 570-595.

Colwell RK, Lees DC. 2000. The mid-domain effect: geometric constraints on the geography of species richness. Trends Ecol Evol 15: 70-76.

Connell JH. 1978. Diversity in tropical rain forests and coral 
reefs. Science 199: 1302-1310.

Currie DJ. 1991. Energy and large-scale patterns of animaland plant-species richness. Am Nat 137: 27-49.

Currie DJ. 2001. Projected effects of climate change on patterns of vertebrate and tree species richness in the conterminous United States. Ecosystems 4: 216-225.

Currie DJ, Mittelbach GG, Cornell HV, Field R, Guegan JF, Hawkins BA, Kaufman DM, Kerr JT, Oberdorff T, O’Brien E, Turner JRG. 2004. Predictions and tests of climatebased hypotheses of broad-scale variation in taxonomic richness. Ecol Lett 7: 1121-1134.

De Boeck HJ, Lemmens CMHM, Gielen B, Bossuyt H, Malchair S, Carnol M, Merckx R, Ceulemans R, Nijs I. 2007. Combined effects of climate warming and plant diversity loss on above- and below-ground grassland productivity. Environ Exp Bot 60: 95-104.

Dirnböck T, Dullinger S, Grabherr G. 2003. A regional impact assessment of climate and land-use change on alpine vegetation. J Biogeogr 30: 401-417.

Dobzhansky T. 1950. Evolution in the tropics. Am Sci 38: 209221.

Evans KL, Greenwood JJD, Gaston KJ. 2005. Dissecting the species-energy relationship. Proc R Soc B 272: 21552163.

Field R, O’Brien EM, Whittaker RJ. 2005. Global models for predicting woody plant richness from climate: development and evaluation. Ecology 86: 2263-2277.

Fonty E, Sarthou C, Larpin D, Ponge JF. 2009. A 10-year decrease in plant species richness on a neotropical inselberg: detrimental effects of global warming? Glob Change Biol 15: 2360-2374.

Francis AP, Currie DJ. 2003. A globally-consistent richnessclimate relationship for angiosperms. Am Nat 161: 523536.

Gaston KJ. 2000. Global patterns in biodiversity. Nature 405: 220-227.

Gordon C, Cooper C, Senior CA, Banks H, Gregory JM, Johns TC, Mitchell JFB, Wood RA. 2000. The simulation of SST, sea ice extents and ocean heat transports in a version of the Hadley Centre coupled model without flux adjustments. Clim Dynam 16: 147-168.

Grime JP. 1974. Vegetation classification by reference to strategies. Nature 250: 26-31.

Guisan A, Theurillat JP. 2000. Assessing alpine plant vulnerability to climate change: a modeling perspective. Integr Asses 1: 307-320.

Hansen AJ, Dale V. 2001. Biodiversity in US forests under global climate change. Ecosystems 4: 161-163.

Hansen AJ, Neilson RP, Dale VH, Flather CH, Iverson LR, Currie DJ, Shafer S, Cook R, Bartlein PJ. 2001. Global change in forests responses of species, communities, and biomes. BioScience 51: 765-779.

Hansen J, Ruedy R, Glascoe J, Sato M. 1999. GISS analysis of surface temperature change. J Geophys Res 104: $30997-$ 31022

Hawkins BA, Albuquerque FS, Araújo MB, Beck J, Bini LM, Cabrero-Sañudo FJ, Castro-Parga I, Diniz-Filho JAF, Ferrer-Castán D, Field R, Gómez JF, Hortal J, Kerr JT, Kitching IJ, León-Cortés JL, Lobo JM, Montoya D, Moreno JC, Olalla-Tárraga MÁ, Pausas JG, Qian H, Rahbek C, Rodríguez MÁ, Sanders NJ, Williams P. 2007. A global evaluation of metabolic theory as an explanation for terrestrial species richness gradients. Ecology 88: 18771888.

Hawkins BA, Field R, Cornell HV, Currie DJ, Guegan JF, Kaufman DM, Kerr JT, Mittelbach GG, Oberdorff T, O’Brien EM, Porter EE, Turner JRG. 2003. Energy, water, and broad-scale geographic patterns of species richness. Ecology 84: 3105-3117.

Hawkins BA, Pausas JG. 2004. Does plant richness influence animal richness? The mammals of Catalonia (NE Spain). Diver Distrib 10: 247-252.

Henry M, Cosson JF, Pons JM. 2010. Modelling multi-scale spatial variation in species richness from abundance data in a complex neotropical bat assemblage. Ecol Model 221: 2018-2027.

Hubbell SP. 2005. Neutral theory in community ecology and the hypothesis of functional equivalence. Funct Ecol 19: 166-172.

Hubbell SP. 2006. Neutral theory in ecology and the evolution of ecological equivalence. Ecology 87: 1397-1398.

Hughes L. 2000. Biological consequences of global warming: is the signal already apparent? Trends Ecol Evol 15: 5661.

Huntley B, Collingham YC, Willis SG, Green RE. 2008. Potential impacts of climatic change on European breeding birds. PLoS One 3: e1439.

Huston MA. 2003. Heat and biodiversity. Science 299: 512513.

Ibáñez I, Clark JS, Dietze MC, Feeley K, Hersh M, LaDeau S, McBride A, Welch NE, Wolosin MS. 2006. Predicting biodiversity change: outside the climate envelope, beyond the species-area curve. Ecology 87: 1896-1906.

Ihm BS, Lee JS, Kim JW, Kim JH. 2007. Relationship between global warming and species richness of vascular plants. J Plant Biol 50: 321-324.

IPCC. 2007. Climate Change 2007: Synthesis Report. Contribution of Working Groups I, II and III to the Fourth Assessment Report of the Intergovernmental Panel on Climate Change (Core Writing Team, Pachauri RK, Reis- 
inger A, eds). IPCC, Geneva.

Jetz W, Rahbek C. 2002. Geographic range size and determinants of avian species richness. Science 297: 1548-1551.

Kim HR, You YH. 2010. Effects of elevated $\mathrm{CO}_{2}$ concentration and increased temperature on leaf related-physiological responses of Phytolacca insularis (native species) and Phytolacca americana (invasive species). J Ecol Field Biol 33: 195-204.

Kim J-H. 1998. Global warming and state of greenhouse gases emission in Korea. J Natl Acad Sci ROK 37: 181-207.

Kim J-H. 2012. Global Warming. Seoul National University Press, Seoul.

Kreft H, Jetz W. 2007. Global patterns and determinants of vascular plant diversity. Proc Natl Acad Sci USA 104: 5925-5930.

Leemans R, Cramer WP. 1991. The IIASA Database for Mean Monthly Values of Temperature, Precipitation and Cloudiness of a Global Terrestrial Grid. RR-91-018. International Institute for Applied Systems Analysis, Luxembourg.

Lemoine N, Böhning-Gaese K. 2003. Potential impact of global climate change on species richness of long-distance migrants. Conserv Biol 17: 577-586.

Lemoine N, Schaefer HC, Böhning-Gaese K. 2007. Species richness of migratory birds is influenced by global climate change. Glob Ecol Biogeogr 16: 55-64.

Lennon JJ, Greenwood JJD, Turner JRG. 2000. Bird diversity and environmental gradients in Britain: a test of the species-energy hypothesis. J Anim Ecol 69: 581-598.

Leyequien E, Verrelst J, Slot M, Schaepman-Strub G, Heitkönig IMA, Skidmore A. 2007. Capturing the fugitive: applying remote sensing to terrestrial animal distribution and diversity. Int J Appl Earth Obs Geoinform 9: 1-20.

Malanson GP. 1993. Comment on modelling ecological response to climate change. Clim Chang 23: 95-109.

Midgley GF, Hannah L, Millar D, Rutherford MC, Powrie LW. 2002. Assessing the vulnerability of species richness to anthropogenic climate change in a biodiversity hotspot. Global Ecol Biogeogr 11: 445-451.

Midgley GF, Hannah L, Millar D, Thuiller W, Booth A. 2003. Developing regional and species-level assessments of climate change impacts on biodiversity in the Cape Floristic Region. Biol Conserv 112: 87-97.

Morin PJ. 2000. Biodiversity's ups and downs. Nature 406: 463-464.

Mutke J, Barthlott W. 2005. Patterns of vascular plant diversity at continental to global scales. Biol Skrif 55: 521-531.

O’Brien EM. 1998. Water-energy dynamics, climate, and prediction of woody plant species richness: an interim general model. J Biogeogr 25: 379-398.
O’Brien EM, Field R, Whittaker RJ. 2000. Climatic gradients in woody plant (tree and shrub) diversity: water-energy dynamics, residual variation, and topography. Oikos 89: 588-600.

Olofsson J, Hickler T, Sykes MT, Arakler T, Baletto E, Berry PM, Bonelli S, Cabeza M, Dubuis A, Guisan A, Kuhn I, Kujala H, Piper J, Rounsevell M, Settele J, Thuiller W. 2008. Climate change impacts on European biodiversity: observations and future projections. Minimisation of an Adaptation to Climate Change Impacts on Biodiversity (MACIS). http://www.macis-project.net. Accessed 3 May 2012.

Palmer MW. 1994. Variation in species richness: towards a unification of hypotheses. Folia Geobot Phytotax 29: 511-530.

Peñuelas J, Prieto P, Beier C, Cesaraccio C, De Angelis P, de Dato G, Emmett BA, Estiarte M, Garadnai J, Gorissen A, Láng EK, Kröel-Dulay G, Llorens L, Pellizzaro G, Riis-Nielsen T, Schmidt IK, Sirca C, Sowerby A, Spano D, Tietema A. 2007. Response of plant species richness and primary productivity in shrublands along a northsouth gradient in Europe to seven years of experimental warming and drought: reductions in primary productivity in the heat and drought year of 2003. Glob Chang Biol 13: 2563-2581.

Pianka ER. 1966. Latitudinal gradients in species diversity: a review of concepts. Am Nat 100: 33-46.

Pimm SL, Gittleman JL. 1992. Biological diversity: Where is it? Science 255: 940.

Pimm SL, Russell GJ, Gittleman JL, Brooks TM. 1995. The future of biodiversity. Science 269: 347-350.

Ricklefs RE. 1987. Community diversity: relative roles of local and regional processes. Science 235: 167-171.

Rocchini D, Balkenhol N, Carter GA, Foody GM, Gillespie TW, He KS, Kark S, Levin N, Lucas K, Luoto M, Nagendra H, Oldeland J, Ricotta C, Southworth J, Neteler M. 2010. Remotely sensed spectral heterogeneity as a proxy of species diversity: recent advances and open challenges. Ecol Inform 5: 318-329.

Roeckner E, Oberhuber JM, Bacher A, Christoph M, Kirchner I. 1996. ENSO variability and atmospheric response in a global coupled atmosphere-ocean GCM. Clim Dyn 12: 737-754.

Rohde K. 1992. Latitudinal gradients in species diversity: the search for the primary cause. Oikos 65: 514-527.

Root TL, Price JT, Hall KR, Schneider SH, Rosenzweig C, Pounds JA. 2003. Fingerprints of global warming on wild animals and plants. Nature 421: 57-60.

Rutherford S, D'Hondt S, Prell W. 1999. Environmental controls on the geographic distribution of zooplankton di- 
versity. Nature 400: 749-753.

Sala OE, Chapin FS III, Armesto JJ, Berlow E, Bloomfield J, Dirzo R, Huber-Sanwald E, Huenneke LF, Jackson RB, Kinzig A, Leemans R, Lodge DM, Mooney HA, Oesterheld M, Poff NL, Sykes MT, Walker BH, Walker M, Wall DH. 2000. Global biodiversity scenarios for the year 2100. Science 287: 1770-1774.

Sætersdal M, Birks HJB, Peglar SM. 1998. Predicting changes in Fennoscandian vascular-plant species richness as a result of future climatic change. J Biogeogr 25: 111-122.

Schlesinger ME, Zhao ZC. 1989. Seasonal climate changes induced by doubled $\mathrm{CO}_{2}$ as simulated by the OSU atmospheric GCM-mixed layer ocean model. J Clim 2: 459495.

Schneider SH. 2001. What is 'dangerous' climate change? Nature 411: 17-19.

Shanahan M, So S, Compton SG, Corlett R. 2001. Fig-eating by vertebrate frugivores: a global review. Biol Rev 76: 529-572.

Shmida A, Wilson MV. 1985. Biological determinants of species diversity. J Biogeogr 12: 1-20.

Shin H, Kim DS, Kim MC, Kim CH, Ku YB, No TH, Bang IC, Lee SJ, Lee EJ, Han SH, Hyun JO. 2009. Conservation Biology in Korea. Worldscience, Seoul.

Sinervo B, Méndez-de-la-Cruz F, Miles DB, Heulin B, Bastiaans E, Villagrán-Santa Cruz M, Lara-Resendiz R, Martínez-Méndez N, Calderón-Espinosa ML, MezaLázaro RN, Gadsden H, Avila LJ, Morando M, De la Riva IJ, Victoriano Sepulveda P, Rocha CF, Ibargüengoytía N, Aguilar Puntriano C, Massot M, Lepetz V, Oksanen TA, Chapple DG, Bauer AM, Branch WR, Clobert J, Sites JW Jr. 2010. Erosion of lizard diversity by climate change and altered thermal niches. Science 328: 894-899.

Stevens GC. 1989. The latitudinal gradient in geographical range: How so many species coexist in the tropics. Am Nat 133: 240-256.

The GFDL Global Atmospheric Model Development Team. 2004. The new GFDL global atmosphere and land model AM2/LM2: evaluation with prescribed SST simulations. J Clim 17: 4641-4673.

Thomas CD, Cameron A, Green RE, Bakkenes M, Beaumont LJ, Collingham YC, Erasmus BFN, De Siquiera MF, Grainger A, Hannah L, Hughes L, Huntley B, Van Jaarsveld AS, Midgley GF, Miles L, Ortega-Huerta MA, Peterson AT, Phillips O, Williams SE. 2004. Extinction risk from climate change. Nature 427: 145-148.

Thuiller W. 2007. Biodiversity: climate change and the ecologist. Nature 448: 550-552.
Thuiller W, Lavorel S, Araújo MB, Sykes MT, Prentice IC. 2005. Climate change threats to plant diversity in Europe. Proc Natl Acad Sci USA 102: 8245-8250.

Turner JRG, Lennon JJ, Lawrenson JA. 1988. British bird species distributions and the energy theory. Nature 335: 539-541.

Ulrich W, Fiera C. 2009. Environmental correlates of species richness of European springtails (Hexapoda: Collembola). Acta Oecol 35: 45-52.

van der Meer J. 2006. Metabolic theories in ecology. Trends Ecol Evol 21: 136-140.

Venevsky S, Veneskaia I. 2003. Large-scale energetic and landscape factors of vegetation diveristy. Ecol Lett 6: 1004-1016.

Vitousek PM. 1994. Beyond global warming: ecology and global change. Ecology 75: 1861-1876.

Walther GR, Post E, Convey P, Menzel A, Parmesan C, Beebee TJC, Fromentin JM, Hoegh-Guldberg O, Bairlein F. 2002. Ecological responses to recent climate change. Nature 416: 389-395.

Wang Z, Brown JH, Tang Z, Fang J. 2009. Temperature dependence, spatial scale, and tree species diversity in eastern Asia and North America. Proc Natl Acad Sci USA 106: 13388-13392.

Warren MS, Hill JK, Thomas JA, Asher J, Fox R, Huntley B, Roy DB, Telfer MG, Jeffcoate S, Harding P, Jeffcoate G, Willis SG, Greatorex-Davies JN, Moss D, Thomas CD. 2001. Rapid responses of British butterflies to opposing forces of climate and habitat change. Nature 414: 65-69.

Whittaker KJ, Willis KJ, Field R. 2001. Scale and species richness: towards a general, hierarchical theory of species diversity. J Biogeogr 28: 453-470.

Whittaker RJ, Nogués-Bravo D, Araújo MB. 2007. Geographic gradients of species richness: a test of the water-energy conjecture of Hawkins et al. (2003) using European data for five taxa. Glob Ecol Biogeogr 16: 76-89.

Willig MR, Lyons SK. 1998. An analytical model of latitudinal gradients of species richness with an empirical test for marsupials and bats in the New World. Oikos 81: 93-98.

Wilson CA, Mitchell JFB. 1987. A doubled $\mathrm{CO}_{2}$ climate sensitivity experiment with a global climate model including a simple ocean. J Geophys Res 92: 13315-13343.

Woodward FI, Kelly CK. 2008. Responses of global plant diversity capacity to changes in carbon dioxide concentration and climate. Ecol Lett 11: 1229-1237.

Worm B, Sandow M, Oschlies A, Lotze HK, Myers RA. 2005. Global patterns of predator diversity in the open oceans. Science 309: 1365-1369. 